\title{
Chemical Constituents of Melon Testa and Rice Husk Powders and Their Potential as Protectant Against Callosobruchus maculatus (Coleoptera: Chrysomelidae)
}

\author{
Akinbuluma Mobolade Dele*, Olaniran Maryam Oyeteju \\ Department of Crop Protection and Environmental Biology, University of Ibadan, Ibadan, Nigeria.
}

\begin{abstract}
How to cite this paper: Akinbuluma Mobolade Dele, Olaniran Maryam Oyeteju. (2021) Chemical Constituents of Melon Testa and Rice Husk Powders and Their Potential as Protectant Against Callosobruchus maculatus (Coleoptera: Chrysomelidae). International Journal of the Science of Food and Agriculture, 5(1), 69-75.

DOI: 10.26855/ijfsa.2021.03.010
\end{abstract}

Received: December 16, 2020

Accepted: January 12, 2021

Published: February 4, 2021

*Corresponding author: Akinbuluma Mobolade Dele, Department of Crop Protection and Environmental Biology, University of Ibadan, Ibadan, Nigeria.

Email: delebuluma@yahoo.com

\begin{abstract}
This study examined the effects of powdered testa of melon Citrullus vulgaris Schrad and husks of rice, Oryza sativa L. on adult C. maculatus and to determine the phytochemicals responsible for their insecticidal property. The experiment was carried out in the laboratory (temperature, $24 \pm 4^{\circ} \mathrm{C}$; r.h, $70 \pm 3 \%$ ). Thirty grammes ( $30 \mathrm{~g}$ ) of cowpea seeds were weighed into each of eight kilner jars and admixed with melon testa and rice husk powders at dosages 1.6\% (w/w), 3.2\% $(\mathrm{w} / \mathrm{w})$ and $4.8 \%(\mathrm{w} / \mathrm{w})$ and mesh sizes, $200 \mathrm{~mm}$ and $500 \mathrm{~mm}$. The experiment was conducted relative to untreated control and pirimiphos-methyl (synthetic chemical). Each jar was infested with 5 pairs of 1-2-day old adult C. maculatus and laid out in a Completely Randomized Design $(r=4)$. Secondary metabolites in the plant samples were determined following standard procedures. Data collected, including mortality, oviposition and adult emergence of $C$. maculatus as well as weight loss in cowpea seeds were analyzed using ANOVA and means separated using DMRT at $5 \%$ level of significance. Percentage mortality of C. maculates ranged from $0 \%$ to $97 \%$ on seeds treated with both melon testa powder and rice husk powders. Mortality of $C$. maculatus from the highest dose of both powders received from $500 \mathrm{~mm}$ was not significantly different $(P<0.05)$ from mortality in pirimiphos-methyl treated seeds. Oviposition by female $C$. maculates reduced from 12.5 in the untreated control to 6.3 and 6.5 on seeds admixed with melon testa powder and rice husk powder, respectively. Significantly lower adult emergence and reduced weight loss were also observed on seeds treated with both powders than on the untreated control. Phytochemical investigations revealed the presence of saponins, tannins, flavanoids, terpenoids, antraquinones, phenols and alkaloids in both powders. In addition, cardiac glycosides were also present in the melon testa powder. Therefore, melon testa and rice husk powders can be used as a grain protectant against Callosobruchus maculatus to reduce the attendant problems with the use of synthetic chemicals thus ensuring food safety and security.
\end{abstract}

\section{Keywords}

Phytochemical screening, Waste powders, Callosobruchus maculatus, Grain protectant 


\section{Introduction}

Cowpea, Vigna unguiculata (L) (Walpers), is an important food in many parts of the world especially in the tropical and subtropical regions. Cowpea plays a critical role in the lives of millions of people in Africa and other parts of the developing world, being a major source of dietary protein. It is a valuable and dependable commodity producing income to farmers and traders [1,2]. Economic losses due to infestation and damage by pests and diseases are a major constraint to cowpea production. Damage by insect pests are the most devastating because they affect all growth stages of cowpea from seedling to emergence and then to storage, thus posing considerable burden to food security and also increase poverty. The cowpea beetle, Callosobruchus maculatus (F.) (Coloptera: Chrysomelidae), is a serious insect pest of pulses like soybeans, pigeon pea, and most especially cowpea [3], accounting for over $90 \%$ damage [4]. Its damage is manifested in several ways such as weight loss, decreased germinability potential and reduction in commercial value. Currently, insect pests control in stored food products relies on the use of synthetic insecticides with some attendant hazards such as pollution of the environment, toxic residue on stored grains, development of resistance by target species, pest resurgence and lethal effect on non-target organisms in addition to direct toxicity to users and health hazards [5]. Thus, it is crucial to develop biopesticides from locally available plant materials [6, 7]. In Nigeria, some earlier researchers have investigated the efficacies of many botanical preparations on $C$. maculates [8, 9, 10, 11]. In majority of the rice producing countries, most of the husks produced is either burnt or dumped as a waste. Given the high concentration of silica present in rice husk, the powder may be useful as grain protectant since materials like diatomaceous earth, which are rich in silica have insecticidal properties [12, 13]. Although melonis used as condiment in soups, flavourant and as snack in most parts of the world $[14,15,16]$, the testa is usually thrown away after it has been separated from the cotyledon. It is thus apt to investigate the insecticidal potential these 'locally available wastes' and to examine the secondary metabolites responsible for their property. Therefore, this study was carried out to examine the insecticidal activities of the powders of rice (Oryza sativa) husk and melon testa relative to a synthetic chemical, pirimiphos-methyl in the control of the cowpea beetle, C. maculatus.

\section{Materials and Methods}

\subsection{Study Area}

All experiments were conducted in the Entomology Research Laboratory, Department of Crop Protection and Environmental Biology (CPEB), University of Ibadan, Nigeria under an ambient temperature of $24 \pm 4^{\circ} \mathrm{C}$ and relative humidity of $70 \pm 3 \%$. Phytochemical screening was carried out at Pharmaceutical and Chemistry laboratory, Department of Pharmacy, University of Ibadan.

\subsection{Cowpea seeds and insecticidal materials}

Cowpea seeds (Ife Brown Variety) were obtained from Institute of Agricultural Research and Training, Moor Plantation Apata, Ibadan, Nigeria. The seeds were disinfested in a deep freezer $\left(-20^{\circ} \mathrm{C}\right)$ for 72 hours and later air-dried in the laboratory to prevent mouldiness and were later sorted before usage.Melon (A16 Papa) was purchased from Bodija market in Ibadan and the testa was hand-removed, dried and milled into fine powder by a burr mill. Rice husk powder was also prepared similarly from rice variety FARO 52, obtained from International Institute of Tropical Agriculture, Ibadan, Nigeria. The powders were sieved from two different mesh sizes $200 \mathrm{~mm}$ and $500 \mathrm{~mm}$ and $0.5 \mathrm{~g}, 1.0 \mathrm{~g}$ and $1.5 \mathrm{~g}$ were weighed, using a digital balance. The dosages of the powder were converted into percentage weight per weight $(\% \mathrm{w} / \mathrm{w})$ to obtain $1.6 \%(\mathrm{w} / \mathrm{w}), 3.2 \%(\mathrm{w} / \mathrm{w})$ and $4.8 \%(\mathrm{w} / \mathrm{w})$ using the formula;

$$
\frac{\text { weight of powder }(g)}{\text { weight of powder }+ \text { weight of cowpea }(g)} \times 100
$$

The synthetic insecticide, actellic dust (active ingredient $0.01 \%$ pirimiphos-methyl) was purchased from an agrochemical store, Dugbe, Ibadan.

\subsection{Insect}

Colony of Callosobruchus maculatus was established in the laboratory with initial stock obtained from heavily infested seeds. Adults were introduced into four jars each containing $300 \mathrm{~g}$ of clean uninfested cowpea (Ife brown variety). After 7 days, the adults were removed and newly emerged adults were sexed and used for the experiment. 


\subsection{Biological assays}

\subsubsection{Mortality of $C$. maculatus}

Each plant powder at dosages $1.6 \%(\mathrm{w} / \mathrm{w}), 3.2 \%(\mathrm{w} / \mathrm{w})$ and $4.8 \%(\mathrm{w} / \mathrm{w})$ received from mesh sizes, 200mm and $500 \mathrm{~mm}$ was tested on $30 \mathrm{~g}$ cowpea seeds weighed into each of eight jars. The control jar did not receive any treatment while $0.02 \mathrm{~g}$ of pirimiphos-methyl was admixed to one of the jars and all jars were shaken to ensure thorough admixture with the cowpea seeds. Thereafter, 5 pairs ( 1 male: 1 female) of adult $C$. maculatus were introduced into each jar with a lid of fine mesh to ensure adequate aeration and the experiment was laid out in Completely Randomized Design with 4 replications. Mortality was recorded at 24, 48, 72 and 96 hours after infestation, with insects considered dead if they did not move when probed with a camel hair brush. Dead adults were removed at each assessment, counted and recorded. Data on percentage adult mortality were corrected using the formula [17]

$\mathrm{PT}=$ Po - Pc / 100 - Pc; where PT = Corrected mortality (\%), Po = Observed mortality (\%), Pc= Control mortality (\%). All data were analyzed using analysis of variance (ANOVA) and means separated using Duncan Multiple Range Test (DMRT) at $5 \%$ level of significance.

\subsubsection{Oviposition, adult emergence of $C$. maculatus and weight loss in cowpea seeds}

Another set-up, as 3.4.1 above was established, with all adult C. maculatus (dead and alive) removed after 7 days. Twenty seeds were randomly selected from each jar and the number of egg laid counted. The total number of eggs deposited on the seeds in each jar was recorded and analyzed using ANOVA and means separated using DMRT. The seeds were carefully returned into the jars and observed daily till emergence of $F_{1}$ progeny. Data on the total number of $F_{1}$ progeny after 40days were analyzed and mean separated using DMRT. Cowpea seeds from each jar were later sieved to remove the dust produced from insect feeding and reweighed by using a sensitive scale and the percentage loss in weight determined as follows;

$$
\text { Percentage }(\%) \text { weight loss }=\frac{\text { initial weight }- \text { final weight }}{\text { final weight }} \times 100
$$

\subsection{Phytochemical investigations}

The phytochemical screening for saponins, tannins, flavonoids, cardiac glycosides, terpenoids, steroids, antraquinones, phenols and alkaloids were carried out using the method described by [18] and reported by [19].

\section{Results and discussion}

\subsection{Mortality}

Effect of different dosages of melon testa and rice husk powders on the mortality of Callosobruchus maculatus is represented in Table 1 and Table 2, respectively. Significant differences $(\mathrm{P}<0.05)$ were observed among treatments with both powders and the untreated control. The highest mortality of $C$. maculatus was recorded on seeds treated with pirimiphos-methyl, but was not significantly higher than mortality caused by the highest dosage $(4.8 \% \mathrm{w} / \mathrm{w})$ of both powders sieved from $500 \mathrm{~mm}$ mesh size. These results indicated that both melon testa and rice husk powders affected the survival of $C$. maculatus at all levels of treatment even though varied with the exposure period and dosages of powder as well as mesh sizes. The highest dose of both powders at $500 \mathrm{~mm}$ mesh size exhibited the highest mortality of $C$. maculatus that were not significantly different from those caused by pirimiphos-methyl suggesting that this powder could serve as an alternative to synthetic chemical. The death of $C$. maculatus elicited by the doses of the powders could be by the blockage of their spiracles leading to suffocation and eventual death [20, 21].

\subsection{Oviposition, $F_{1}$ emergence and weight loss in cowpea seeds}

Table 3 shows that oviposition by female $C$. maculatus significantly $(\mathrm{P}<0.05)$ reduced from 15.8 in the untreated control to 6.3 and 6.5 on seeds admixed with $4.8 \%(\mathrm{w} / \mathrm{w})$ melon testa powder and rice husk powder, respectively. There was no significant difference ( $\mathrm{P}>0.05$ ) in the number of eggs laid on cowpea seeds admixed with $4.8 \%(\mathrm{w} / \mathrm{w})$ sieved from $500 \mathrm{~mm}$ of both powders and pirimiphos-methyl.

Table 1. Mortality of adult Callosobruchus maculatus on cowpea seeds admixed with melon testa powder

\begin{tabular}{cccccc}
\hline Mesh size/Control & Dosage & \multicolumn{3}{c}{ Percentage mortality over 24 - 96 h after infestation } \\
\hline$(\mathrm{mm})$ & {$[\%(\mathrm{w} / \mathrm{w})]$} & 24 & 48 & 72 & 96 \\
200 & 1.6 & $9.2 \mathrm{~b}$ & $15.8 \mathrm{~b}$ & $29.3 \mathrm{~b}$ & $38.4 \mathrm{~b}$ \\
& 3.2 & $22.5 \mathrm{c}$ & 29.4c & 42.0c & $58.1 \mathrm{c}$ \\
\hline
\end{tabular}




\begin{tabular}{|c|c|c|c|c|c|}
\hline & 4.8 & 23.6cd & $31.4 \mathrm{c}$ & 42.1c & $61.0 \mathrm{c}$ \\
\hline \multirow[t]{3}{*}{500} & 1.6 & 24.5cde & $34.7 \mathrm{~cd}$ & $44.1 c$ & $60.3 c$ \\
\hline & 3.2 & 27.9cde & 36.0cd & $43.6 c$ & $62.5 c$ \\
\hline & 4.8 & 31.5cde & 42.1de & $53.8 \mathrm{~d}$ & 87.3d \\
\hline Untreated & 0.0 & $0.0 \mathrm{a}$ & $0.0 \mathrm{a}$ & $0.0 \mathrm{a}$ & $0.0 \mathrm{a}$ \\
\hline Pirimiphos-methyl & 0.02 & $45.0 \mathrm{f}$ & $47.9 \mathrm{e}$ & $55.4 d$ & $96.5 d$ \\
\hline
\end{tabular}

Means in the same columns with different alphabets are significantly different $(\mathrm{P}<0.05)$

Table 2. Mortality of Callosobruchus maculatus on cowpea seeds admixed with rice husk powder

\begin{tabular}{|c|c|c|c|c|c|}
\hline \multirow{2}{*}{$\begin{array}{l}\text { Mesh size/Control } \\
\qquad(\mathrm{mm})\end{array}$} & \multirow{2}{*}{$\begin{array}{c}\text { Dosage } \\
{[\%(w / w)]}\end{array}$} & \multicolumn{4}{|c|}{ Percentage mortality over 24-96 h after infestation } \\
\hline & & 24 & 48 & 72 & 96 \\
\hline \multirow[t]{3}{*}{200} & 1.6 & $6.64 \mathrm{a}$ & $14.9 \mathrm{~b}$ & $36.2 b$ & $41.2 \mathrm{bc}$ \\
\hline & 3.2 & 22.1bc & $34.6 \mathrm{~d}$ & $46.4 \mathrm{~d}$ & $53.9 c$ \\
\hline & 4.8 & 11.2ab & 19.0c & 43.6cd & $50.0 \mathrm{c}$ \\
\hline \multirow[t]{3}{*}{500} & 1.6 & $24.5 c$ & 33.0cd & $39.1 \mathrm{bc}$ & $44.8 \mathrm{bc}$ \\
\hline & 3.2 & $25.5 c$ & $31.5 \mathrm{~cd}$ & $46.4 \mathrm{~d}$ & $57.3 c$ \\
\hline & 4.8 & $26.1 c$ & $36.2 d$ & $53.8 \mathrm{~d}$ & $80.5 d$ \\
\hline Untreated & 0.0 & $0.0 \mathrm{a}$ & $0.0 \mathrm{a}$ & $0.0 \mathrm{a}$ & $0.0 \mathrm{a}$ \\
\hline Pirimiphos-methyl & 0.02 & 27.9c & 42.1 & $58.6 \mathrm{e}$ & $97.2 \mathrm{~d}$ \\
\hline
\end{tabular}

Means in the same columns with different alphabets are significantly different $(\mathrm{P}<0.05)$

Table 3. Effects of melon testa powder and rice husk powder on the oviposition of $C$. maculatus

\begin{tabular}{cccc}
\hline $\begin{array}{c}\text { Mesh size/Control } \\
(\mathrm{mm})\end{array}$ & $\begin{array}{c}\text { Dosage } \\
{[\%(\mathrm{w} / \mathrm{w})]}\end{array}$ & Melon Testa powder & Rice Husk powder \\
\hline 200 & 1.6 & $12.5 \mathrm{~b}$ & $11.0 \mathrm{~cd}$ \\
& 3.2 & $11.3 \mathrm{~b}$ & $10.3 \mathrm{c}$ \\
& 4.8 & $11.0 \mathrm{~b}$ & $9.5 \mathrm{c}$ \\
500 & 1.6 & $10.5 \mathrm{~b}$ & $9.3 \mathrm{c}$ \\
& 3.2 & $10.5 \mathrm{~b}$ & $6.3 \mathrm{ab}$ \\
Untreated & 4.8 & $6.3 \mathrm{a}$ & $14.3 \mathrm{~d}$ \\
\hline
\end{tabular}

Means in the same columns with different alphabets are significantly different $(\mathrm{P}<0.05)$

The mean number of $F_{1}$ progeny of $C$. maculatus in the treated and untreated cowpea seeds arising from possible oviposition is presented in Table 4. Adult emergence was highest in the untreated control in both melon testa powder (8.42) and rice husk powder (8.50) treatments and reduced with increasing concentration of powders and mesh size. There was no significant difference in the number of emerged adult $C$. maculatusbetween the treatment with $1.5 \mathrm{~g}$ (500mm mesh size) of melon testa powder and pirimiphos-methyl. Significantly higher number of eggs laid by female C. maculatus and $\mathrm{F}_{1}$ adult emergence in the untreated control than in other treatments suggest that the powders contain certain compounds that are ovicidal to the insects which invariably reduced emergence. Table 4 also shows the weight loss in cowpea seeds treated with melon testa powder and rice husk powder, due to insect feeding. Grain weight loss was highest in the untreated control (18.4) and significantly reduced with increasing dosage of both melon testa pow- 
ders (10.6) and rice husk powders (7.3). Result on weight loss in the cowpea seeds agrees with earlier reports that weight loss in seeds was related to the population of emerged $F_{1}$ adults [22, 23].

\subsection{Phytochemical Screening}

The result of the phytochemical analysis of melon testa powder and rice husk powder is presented in Table 5. Tannins, flavonoids, cardiac glycosides, terpenoids, antraquinones and phenols were detected in melon testa powder while tannins, flavonoids, terpenoids, antraquinones and phenols were detected in the filtrate of rice husk powder. Alkaloids were also present in a significant amount in both melon testa and rice husk powders while saponins were present in significant amount in rice husk powder. Steroids were not detected in either of the powders. The two powders used in this study are rich in secondary metabolites and these may be responsible for their inherent insecticidal activities. This is in agreement with earlier reports that flavonoids [24], saponins [25, 26], alkaloids [27, 28] and terpenoids [29] are responsible for antifeedant and other insecticidal activities against many species.

Table 4. Effect of melon testa powder and rice husk powder on $F_{1}$ progenyof $C$. maculatusand weight loss in cowpea seeds

\begin{tabular}{|c|c|c|c|c|c|}
\hline \multirow{2}{*}{$\begin{array}{c}\text { Mesh size/Control } \\
\text { (mm) }\end{array}$} & \multirow{2}{*}{$\begin{array}{c}\text { Dosage } \\
{[\%(w / w)]}\end{array}$} & \multicolumn{2}{|c|}{ Mean no. of $F_{1}$ progeny } & \multicolumn{2}{|c|}{ Mean \% weight loss in seeds } \\
\hline & & Melon Testa powder & Rice Husk powder & Melon Testa powder & Rice Husk powder \\
\hline \multirow[t]{3}{*}{200} & 1.6 & $6.68 \mathrm{e}$ & $6.4 \mathrm{e}$ & 6.9ab & $7.1 \mathrm{~b}$ \\
\hline & 3.2 & $5.76 \mathrm{~d}$ & $5.6 \mathrm{~d}$ & 7.4ab & $7.0 \mathrm{~b}$ \\
\hline & 4.8 & $5.23 d$ & $5.3 d$ & 7.7ab & $7.0 \mathrm{~b}$ \\
\hline \multirow[t]{3}{*}{500} & 1.6 & $4.09 \mathrm{c}$ & $3.7 \mathrm{bc}$ & 6.8ab & $6.3 b$ \\
\hline & 3.2 & $3.87 \mathrm{bc}$ & $4.0 \mathrm{c}$ & $6.6 a$ & $7.6 b$ \\
\hline & 4.8 & 3.33ab & $3.5 b$ & $10.6 b$ & $7.3 \mathrm{~b}$ \\
\hline Untreated & 0.0 & $8.42 f$ & $8.5 f$ & $11.6 \mathrm{c}$ & $18.2 \mathrm{c}$ \\
\hline Pirimiphos-methyl & 0.02 & $2.72 \mathrm{a}$ & $2.8 \mathrm{a}$ & $4.4 \mathrm{a}$ & 2.9a \\
\hline
\end{tabular}

Means in the same columns with different alphabets are significantly different $(\mathrm{P}<0.05)$

Table 5. Phytochemical screening of Melon testa powder and Rice husk powder

\begin{tabular}{|c|c|c|}
\hline Phytochemicals & Melon testa powder & Rice husk powder \\
\hline Saponins & + & ++ \\
\hline Tannins & + & + \\
\hline Flavonoids & + & + \\
\hline Cardiac glycosides & + & - \\
\hline Terpenoids & + & + \\
\hline Steroids & - & - \\
\hline Antraquinones & + & + \\
\hline Phenols & + & + \\
\hline Alkaloids & ++ & ++ \\
\hline
\end{tabular}

Key: + = trace amount, ++ = significant amount - = not detected

\section{Conclusion}

Rice husk and melon testa powders at mesh size $500 \mathrm{~mm}$ could be used in the management of Callosobruchus maculatus. This will reduce the high cost of pesticide usage and reduce the risks of toxic residues in human food and animal feed. Waste from other plant materials should be explored as potential grain protectants in the storage environments.

\section{Acknowledgements}

We are grateful to the management of the Nigerian Stored Produce Research Institute for providing some of the equipment used for the experiments and to Dr. O. S. Olubode and Mr. D. O. Omobusuyi of the Department of Crop Protection and Environmental Biology, University of Ibadan, for their technical assistance. 


\section{References}

[1] Singh, B. B., Ehlers, J. D., Sharma, B., Freire Filho, F. R. (2002). Recent progress in cowpea breeding. In: Fatokun C. A., Tarawali, S. A., Singh, B. B., Kormawa, P. M., Tamo, M. (eds.). Challenges and Opportunities for Enhancing Sustainable Cowpea Production. International Institute of Tropical Agriculture, Ibadan, Nigeria, pp. 22-40.

[2] Langyintuo, A. S., Lowenberg-DeBoer, J., Faye, M., Lambert, D., Ibro, G., Moussa, B., Kergna, A., Kushwaha, S., Musa, S. and Ntoukam G. (2003). Cowpea supply and demand in West Africa. Field Crops Resistance, 82, 215-231.

[3] Chaubey, M. K. (2008). Fumigant Toxicity of Essential Oils from Some Common Spices against Pulse Beetle, Callosobruchus chinensis (Coleoptera: Bruchidae). Journal of oleo science, 57(3), 171-179.

[4] Ekeh, F. N., Onah, I. E., Atama, C. I., Ivoke, N., and Eyo, J. E. (2013). Effectiveness of botanical powders against Callosobruchus maculatus (Coleoptera: Bruchidae) in some stored leguminous grains under laboratory conditions. African Journal of Biotechnology, 12(12), 1384-1391.

[5] Ileke, K. D. and Olotuah, O. F. (2012). Bioactivity of Anacardium occidentale (L) and Allium sativum (L) Powders and Oils Extracts against Cowpea Bruchid, Callosobruchus maculatus (Fab.) (Coleoptera: Chrysomelidae). International Journal of Biology, 4, 6-103.

[6] Isman, M. B. (2008). Botanical Insecticides: For richer, for poorer. Pest Management Science, 64: 8-11.

[7] Aboaba, S. A., Mobilawon, F. E., and Akinbuluma, M. D. (2019). Chemical constituent and insecticidal activity of the essential oils from Thevetia neriifolia Juss. on Callosobruchus maculatus (Coleoptera: Chrysomelidae). Journal of Entomology and Zoology Studies, 7, 394-400.

[8] Idoko, J. E. and Adesina, J. M. (2012). Evaluation of the powder of Piper guineense and pirimiphos-Methly for the control of cowpea beetle Callosobruchus maculatus (F.). Journal of Agricultural Technology, 8(4), 1365-1374.

[9] Idoko J. E. (2015). Entomotoxic effects of banana peel extract and powder against Callosobruchus maculatus (F.) infesting cowpea in storage. In: Amos, T. T., Adekunle, V. A. J., and Badejo, A. A. (Editors): Food security and climate change: The way forward. Proceedings 8th Annual Agricultural Conference, The Federal University of Technology Akure, Nigeria, pp. 103-106.

[10] Akinbuluma, M. D. and Adeyemi, W. A. (2017). Laboratory evaluation of Cedrela odorata (L) for the management of cowpea beetle, Callosobruchus maculatus (F.) in Ibadan Nigeria. Nigerian Journal of Ecology, 16(2), 120-127.

[11] Akinbuluma, M. D. (2020). Volatile oils from Cedrela odorata L. as protectants against Sitophilus zeamais (Coleoptera: Curculionidae). American Journal of Essential Oils and Natural Products, 8(3), 20-29.

[12] Nwaubani, S. I., Opit, G. P., Otitodun, G. O. and Adesida, M. A. (2014). Efficacy of two Nigeria derived diatomaceous earths against Sitophilus oryzae (Coleoptera: Curculionidae) and Rhyzopertha dominica (Coleoptera: Bostrichidae) on wheat. Journal of Stored Products Research, 59, 9-16.

[13] Otitodun, G. O., Opit, G. P., Nwaubani, S. I., Okonkwo, and Gautam, S. G. (2015). Efficacy of Nigeria-derived diatomaceous earth, botanicals and riverbed sand against Sitophilus oryzae andRhyzopertha dominicaon wheat. African Crop Science Journal, 23(3), 279-293.

[14] King, R. D. and Onuora, O. J. (1983). Aspects of melon seed protein characteristics. Food Chemistry, 14, 65-77.

[15] El-Adaway, T. A. and Taha, K. M. (2001). Characteristics and composition of different seed oils and flours. Food Chemistry, 74, 47-54.

[16] Edelduok, E., Akpabio, E., Eyo, J., and Ekpe, E. (2012). Bio-insecticidal potentials of testa powder of melon, Citrullus vulgaris Schrad for reducing infestation of maize grains by the maize weevil, Sitophilus zeamais Motsch, Journal of Biology, Agriculture and Healthcare, 2(8), 13-17.

[17] Abbott W. S. (1925). A method of computing the effectiveness of an insecticide. Journal of Economic Entomology, 18, 265-267.

[18] Oloyede, I. O. (2005). Chemical Profile of Unripe Pulp of Carica papaya. Pakistan Journal of Nutrition, 4(6), $379-381$.

[19] Akinbuluma, M. D. Yeye, E. O., and Ewete, F. K. (2015). Qualitative Phytochemical screening of Acalypha fimbriata, and its methanol extract as protectant against Sitophilus zeamais on stored maize. Journal of Natural Science Research, 5, $122-132$.

[20] Caswell, G. H. (1981). Damage to stored cowpeas in northern Nigeria. Samaru Journal of Agricultural Research, 1, 11-19.

[21] Sokker, R. F., Hussein, M. A., Salwa, M. S. Ahmed, and Ragaa, K. A. Hamed. (2012). Effect of katel-sous dust and clove powder and their mixtures on the cowpea seed beetle, Callosobruchus maculatus (F.) (Coleoptera: Bruchidae). Egyptian Academic Journal of Biological Science, 4(1), 3-33.

[22] Okonkwo, E. U. and Okoye, W. I. (1996). The efficacy of four seed powders and the essential oils as protectants of cowpea and maize grains against infestation by Callosobruchus maculatus (F.) (Coleoptera: Bruchidae) in Nigeria. International Journal of Pest Management, 42, 143-146.

[23] Akinbuluma, M. D. and Ewete, F. K. (2014). Comparative efficacy of extracts of Azadirachta indica and Piper guineense with pirimiphos - methyl in the control of Sitophilus zeamais on stored maize. Journal of Biology, Agriculture and Health care, 4, 327-335. 
[24] Wakako, O., Shuichi, D., Masakazu, A., and Sciji, O. (2012). Antifeedant activity of flavonoids and related compounds against the subterranean termite Coptotermes formosanus Shiraki. Journal of Wood Science, 46(2), 149-153.

[25] De Geyter, E., Geelen, D., and Smagghe, G. (2007). First results on the insecticidal action of saponins. Communication in Agricultural and Applied Biological Sciences, 72(3), 645-648.

[26] Chaieb, I. (2010). Saponins as insecticides: a review. Tunisian Journal of Plant Protection, 5, 39-50.

[27] Wanjala, W. C., Teresa, A., George, O. O., and Kweyu, P. L. (2009). Antifeedant activities of the Erythrinaline Alkaloids from Erythrina latissima against Spodoptera littoralis (Lepidoptera: Noctuidae). Record of National Production, 3(2), 96-103.

[28] Akinbuluma, M. D., Ewete, F. K., and Torto, B. (2017). Isolation and identification of compounds from Piper guineense seed extract for the management of Sitophilus zeamais on stored maize. In Peer-Reviewed Conference Proceedings of the First All Africa Postharvest Congress and Exhibition on Reducing food losses and waste: Sustainable Solutions for Africa held at Safari Park Hotel, Nairobi, Kenya between 28th and 31st March, 2017.

[29] Duke, S. D. (1991). Plant terpenoids as pesticides: toxicology of plant and fungal compounds. In Handbook of Natural Toxins. Pp. 269-289. 